\title{
Pengembangan Buku Siswa Membaca Menulis Permulaan Berbasis Budaya Menggunakan Prosedur ADDIE Untuk Kelas 1 SD
}

\author{
Magdalena Chori Rahmawati \\ Universitas Katolik Indonesia Atma Jaya \\ magdalena.chori@atmajaya.ac.id \\ Francine Avantie Samino \\ Universitas Katolik Indonesia Atma Jaya \\ francine.avanti@atmajaya.ac.id \\ Murniati Agustian \\ Universitas Katolik Indonesia Atma Jaya \\ murniati.agustian@atmajaya.ac.id \\ Noviria Retno Revaria \\ Universitas Katolik Indonesia Atma Jaya \\ noviria.201803550005@student.atmajaya.ac.id \\ Teresa Gita Ernestya \\ Universitas Katolik Indonesia Atma Jaya \\ teresa.201803550008@student.atmajaya.ac.id
}

\begin{abstract}
The development research aims to produce a book for students to start reading and writing based on the Mentawai culture. The development of student book products refers to the ADDIE development mode. The results of the development research show the student books are categorized verry well from the aspect of material content, material accuracy, linguistics with the accumulation of the validity score range wich is $92 \%$, while the student book design is categorized as verry good from aspects of book size, book cover design, book content design, book content illustrations with an accumulation of the validity score range of $94,26 \%$. This shows that student book can be used in learning activities. The results of the analysis obtained criteria $81 \%-100 \%$, then the qualified student's book was verry good for use in learning. The culture-based reading and writing students' book that was developed is said to be suitable for use learning activities.
\end{abstract}

Keywords: student book development, reading and writing beginnings, culture, ADDIE

\section{Pendahuluan}

Membaca dan menulis permulaan merupakan pembelajaran awal di kelas 1 SD. Membaca menulis permulaan adalah keterampilan dasar yang harus dimiliki supaya siswa dapat menuangkan gagasan, pikiran, dan perasaan baik secara lisan maupun tulisan. Kemampuan membaca permulaan adalah keterampilan dasar pada aspek bahasa yang dapat dijadikan bekal untuk memasuki perkembangan selanjutnya (Nahdi,2020). Namun sayangnya dari hasil pengukuran skala internasional maupun nasional menunjukkan bahwa keterampilan membaca pemahaman siswa Indonesia masih tergolong rendah. 
Hasil studi PISA (Program for International Student Assessment) sumber www.kemendikbud.go.id menunjukkan kemampuan membaca anak Indonesia berada di peringkat 6 dari bawah yaitu peringkat 74. Hasil Asesmen Kompetensi Siswa Indonesia (AKSI) atau Indonesia National Assessment Program-INAP yang diselenggarakan tahun 2016 menunjukkan siswa Indonesia khususnya dalam keterampilan membaca pemahaman masih tergolong rendah. Penelitan yang dilakukan Sukartiningsih (2005: 97) juga menunjukkan rendahnya keterampilan membaca dan menulis peserta didik SD.

Pembelajaran membaca dan menulis permulaan dalam kurikulum yang berlaku menjadi bagian dari pembelajaran berbasis tema. Buku berbasis tema yang digunakan sudah sarat dengan kalimat-kalimat panjang dan tidak menghadirkan situasi konkrit/nyata yang sesuai dengan tingkat perkembangan siswa usia kelas 1 SD. Menurut Piage (dalam Marhaeni, 2013) anak usia SD berada pada tahap operasional konkrit. Karakteristik belajar anak pada tahap ini adalah belajar melalui hal- hal nyata sesuai dengan lingkungan dan budaya setempat. Menurut Vygotsky dalam Mutiah (210:103) "Anak menemukan pengetahuannya dalam dunia sosialnya atau lingkungannya". Unsur-unsur budaya seperti bahasa, sistem pengetahuan, sistem teknologi dan peralatan, kesenian, sistem mata pencaharian dan ekonomi, religi, sistem kekerabatan dan organisasi kemasyarakatan adalah lingkungan keseharian siswa.

Menurut Usawatun dalam Nahel (2021: 1) komponen kelayakan isi buku siswa meliputi: (a) cakupan materi yang memuat keluasan materi dan kedalaman materi; (b) akurasi materi yang memuat akurasi fakta, konsep, prosedur/metode, serta teori; (c) kemutakhiran yang memuat kesesuaian dengan perkembangan ilmu, keterkinian fitur, kutipan yang up to date, satuan yang digunakan adalah satuan sistem internasional; (d) merangsang keingintahuan meliputi menumbuhkan rasa ingin tahu, memberi tantangan untuk belajar lebih jauh, (e) mengembangkan kecakapan hidup, di dalamnya memuat pengembangkan kecakapan hidup, sosial dan akademik. Buku siswa sebaiknya disusun dengan menggunakan bahasa sederhana, menarik, dilengkapi gambar, keterangan, isi buku, dan daftar pustaka sehingga membantu guru dan siswa dalam mendalami ilmu pengetahuan sesuai dengan mata pelajaran masing-masing (Prastowo, 2011:79).

Berdasarkan hasil wawancara dengan beberapa pegiat sosial dari APTIK (Asosiasi Perguruan Tinggi Katolik) dan mahasiswa asal Mentawai diperoleh informasi rendahnya kemampuan dasar baca tulis di kepulauan Mentawai khususnya Siberut. Kesulitan siswa dalam membaca dan menulis karena masih banyak yang tidak bisa berbahasa Indonesia. Hasil wawancara dengan guru diperoleh informasi bahwa buku siswa yang digunakan masih mengacu pada buku yang ditentukan oleh pemerintah. Tema-tema dalam buku siswa sudah ditentukan sehingga tidak sesuai dengan konteks lingkungan siswa. Pembelajaran menggunakan tema-tema yang intinya menghubungkan pelajaran yang satu dengan pelajaran yang lainnya. Siswa harus bisa membaca dan menulis terlebih dahulu baru bisa belajar dengan menggunakan buku siswa tematik yang sudah ada.

Ketidaksesuaian buku siswa yang digunakan di sekolah dengan karakteristik siswa SD sejalan dengan pendapat Gumono (2017) dalam penelitiannya yang berjudul "Analisis Bahan Ajar Membaca yang Tersedia untuk Siswa Sekolah Dasar di Provinsi Bengkulu. Hasil penelitian Gumono menunjukkan bahwa tema yang disajikan dalam buku siswa tidak sesuai dengan karakteristik siswa SD di Provinsi Bengkulu dan materi yang disajikan tidak memuat lingkungan siswa.

Berdasarkan permasalahan di atas dan mengingat pentingnya pembelajaran membaca menulis permulaan, maka peneliti tertarik untuk melakukan penelitian 
pengembangan untuk menghasilkan produk buku siswa yang bisa menunjang pelaksanaan pembelajaran membaca menulis permulaan yang kontekstual sesuai dengan lingkungan budaya siswa untuk daerah Kepulauan Mentawai khususnya daerah Siberut.

\section{Metode}

Penelitian ini merupakan penelitian pengembangan dengan menggunakan prosedur pengembangan ADDIE. Langkah-langkah pengembangan dengan model ADDIE menurut Branch (2009: 6) yaitu (1) analisis kebutuhan (analysis), (2) merancang produk awal atau draft buku siswa membaca menulis permulaan (design), (3) pengembangan buku siswa membaca menulis permulaan (development), (4) uji coba buku siswa membaca menulis permulaan (implementation), (5) evaluasi produk (evaluation).

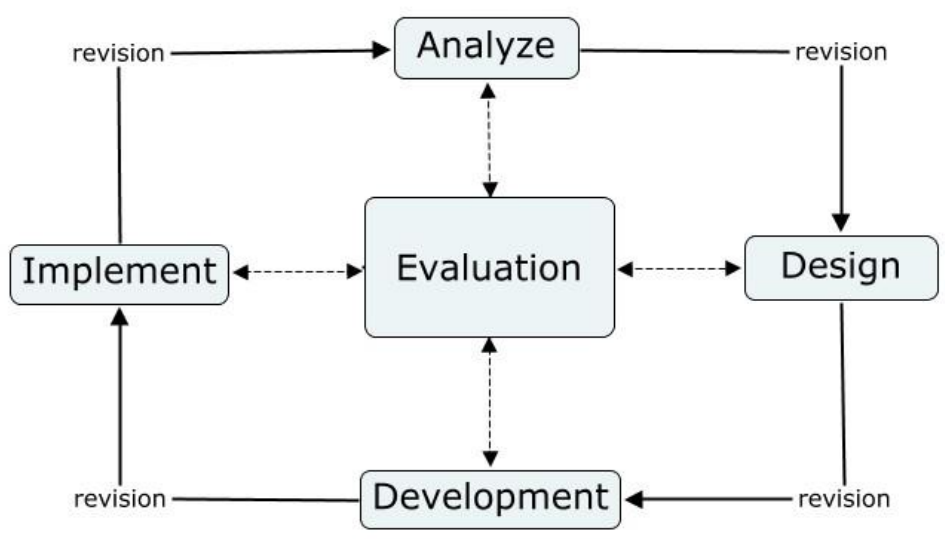

\section{Gambar 1. Tahapan Model Pengembangan ADDIE (Sumber: Branch,2009:6)}

Dalam penelitian ini terdapat keterbatasan dimana tahapan model pengembangan baru bisa dilaksanakan sampai tahap keempat yaitu implementasi. Hal ini dikarenakan situasi pandemi covid-19 sehingga tahap evaluasi penggunaan buku siswa membaca menulis permulaan berbasis budaya Mentawai yang direncanakan dilaksanakan di kepulauan Mentawai belum dapat dilaksanakan. Partisipan dalam penelitian ini adalah guru dan siswa SD di daerah Siberut Mentawai. Partisipan untuk uji coba satu-satu ada 4 orang siswa dan untuk uji coba kelompok kecil 24 siswa.

Terdapat 3 instrumen penelitian yang digunakan yaitu instrumen observasi, instrumen wawancara, dan instrumen angket. Instrumen untuk observasi ada 2 macam yaitu lembar observasi untuk tahap analisis pada proses belajar dan lembar observasi tahap implementasi uji coba satu-satu dan uji coba kelompok kecil, Instrumen untuk wawancara ada 3 macam yaitu: 1) lembar wawancara kepala sekolah dan guru kelas 1 pada tahap analisis, 2) Lembar wawancara siswa kelas 1 pada tahap analisis, dan 3) lembar wawancara pada tahap implementasi. Instrumen angket yang digunaka ada 2 yaitu angket untuk ahli media dan ahli materi.

Teknik pengumpulan data yang digunakan adalah observasi, wawancara,dan angket. Observasi dilakukan dua kali yaitu pada tahap analisis dan pada tahap implementasi. Observasi awal bertujuan untuk mengamati proses pembelajaran membaca menulis permulaan. Data yang diperoleh pada observasi awal dijadikan acuan untuk merancang produk buku siswa. Observasi pada tahap implementasi bertujuan untuk uji coba produk yang dikembangkan. Wawancara dilakukan pada tahap analisis. Wawancara dilakukan dengan guru kelas 1, siswa kelas 1, dan kepala 
sekolah, untuk melihat sejauh mana proses pembelajaran menulis permulaan di kepulauan Mentawai sehingga mendapat gambaran untuk merancang produk buku siswa. Angket yang digunakan dalam penelitian ada 2, yaitu angket untuk ahli media dan ahli materi. Tujuan pengambilan data melalui angket adalah untuk mengetahui penilaian ahli media dan ahli materi sebagai validator kelayakan buku siswa.

Teknik analisis data dalam penelitian ini ada dua yaitu analisis data kualitatif dan analisis data kuantitatif. Analisis data kualitatif dilakukan pada data analisis kebutuhan, hasil validasi produk, dan uji coba kelayakan buku siswa. Data analisis kebutuhan diperoleh dari hasil observasi pembelajaran, wawancara dengan guru kelas 1 SD, dan wawancara dengan siswa asal Mentawai.Data validasi produk diperoleh dari ahli media dan ahli materi. Data hasil uji coba kelayan produk diperoleh dari guru SDN 07 Madobbag Siberut Mentawai dan SD Fransiskus Sikabaluan Mentawai.

Analisis data kuantitatif dilakukan pada hasil validasi produk yang dilakukan oleh ahli materi dan ahli media dalam bentuk angket pada tahap pengembangan. Angket menggunakan skala likert yang terdidi dari lima kategori. Skala Likert yang digunakan terdiri dari lima kategori alternatif pilihan yang dapat dilihat dari tabel 1. Data yang diperoleh selanjutnya dianalisis dengan menggunakan rumus persentase (Arikunto, 2008:35)

$$
\mathrm{P}=\frac{\sum x}{\sum x i} \mathrm{x} 100 \%
$$

Tabel 1. Skala Likert

\begin{tabular}{cc}
\hline Skor & Kategori \\
\hline 1 & Sangat tidak baik \\
\hline 2 & Kurang baik \\
\hline 3 & Cukup baik \\
\hline 4 & Baik \\
\hline 5 & Sangat baik \\
\hline
\end{tabular}

(Sugiyono, 2014:94-95)

Selanjutnya pengambilan keputusan dari analisis data menggunakan skala kualifikasi sebagai pedoman dalam menentukan kesimpulan. Kriteria kelayakan hasil validasi disajikan dalam tabel berikut.

Tabel 2. Tabel Kelayakan Produk

\begin{tabular}{ccc}
\hline Tingkat Pencapaian & Kualifikasi & Keterangan \\
\hline $85 \%-100 \%$ & Sangat baik & Tidak perlu direvisi \\
\hline $75 \%-84 \%$ & Baik & Tidak perlu direvisi \\
\hline $65 \%-74 \%$ & Cukup & Direvisi \\
\hline $55 \%-64 \%$ & Kurang & Direvisi \\
\hline $0-54 \%$ & Kurang Sekali & Direvisi \\
\hline & & (Arikunto, 2008:35)
\end{tabular}

\section{Hasil}

Tahapan penelitian pengembangan dengan model ADDIE yang dilakukan dalam penelitian ini hanya sampai 4 tahap karena situasi pandemi covid-19 tahap kelima yaitu evalusai penggunaan buku ke siswa di Mentawai belum dapat dilaksanakan. Berikut hasil dari 4 tahap yang dikalukan dalam penelitian ini.

Tahap pertama: analisis kebutuhan. Pada tahap ini dilakukan analisis kebutuhan melalui observasi dan wawancara. Observasi dilakukan di SDN 07 Madobbag. Wawancara dilakukan kepala sekolah, guru kelas 1, dan siswa kelas 1 SDN 07 
Madobabag. Hasil observasi dan wawancara menunjukkan beberapa kesulitan guru dalam mengajarkan membaca menulis permulaan: 1) mengelola waktu pembelajaran sesuai dengan tema yang telah ditentukan, sementara membaca menulis permumalaan perlu waktu cukup lama, 2) mengelola pembelajaran berbasis tema sesuai waktu yang diharapkan dengan menggunakan tema yang sudah ditentukan dalam buku tematik, Hal ini sejalan dengan hasil penelitian Artapati dan Budiningsih (2017: 185- 200) menyatakan hambatan guru melaksanakan kurikulum 2013 antara lain jumlah materi pembelajaran yang banyak namun tidak sesuai dengan alokasi waktu yang disediakan. 3) ketidaksesuaian tema dengan lingkungan belajar siswa. Hasil analisis kebutuhan menunjukkan diperlukan buku siswa yang kontekstual seuai dengan karakteristik siswa dan lingkungan budaya siswa.

Tahap kedua: desain. Desain buku menggambarkan keseluruhan hubungan antar bagian dalam buku siswa. Komponen-komponen dalam buku siswa meliputi: 1) tujuan pembelajaran yang jelas, 2) petunjuk bagi siswa, 3) materi tentang pengenalan huruf A-Z, 4) latihan soal-soal sesuai materi, 5) kegiatan belajar yang relevan antara materi kehidupan sehari-hari sesuai budaya Mentawai, dan 6) soalsoal evaluasi. Sampul buku siswa diberi judul "Asyiknya Mengenal Huruf A-Z". Halaman sampul memuat gambar huruf-huruf dengan aneka ukuran dan warna agar menarik siswa untuk belajar membaca menulis permulaan. Materi dalam buku disesuaikan dengan komptensi dasar kelas satu awal yaitu siswa mampu mengenal huruf abjad.

Tahap ketiga: development (pengembangan). Pengembangan buku siswa meliputi penentuan isi materi, validasi dan produksi. Isi materi dikembangkan dari Kompetensi Dasar (KD) siswa kelas 1 SD. Buku siswa dikembangkan menjadi buku panduan sekaligus buku aktivitas yang merangsang siswa untuk terlibat aktif dalam proses pembelajaran membaca dan menulis permulaan. Materi pengenalan huruf dikembangkan dengan menggunakan kosa kata yang sesuia dengan budaya lokal Mentawai seperti rumah adat, makanan tradisional, dan hewan asli Mentawai.
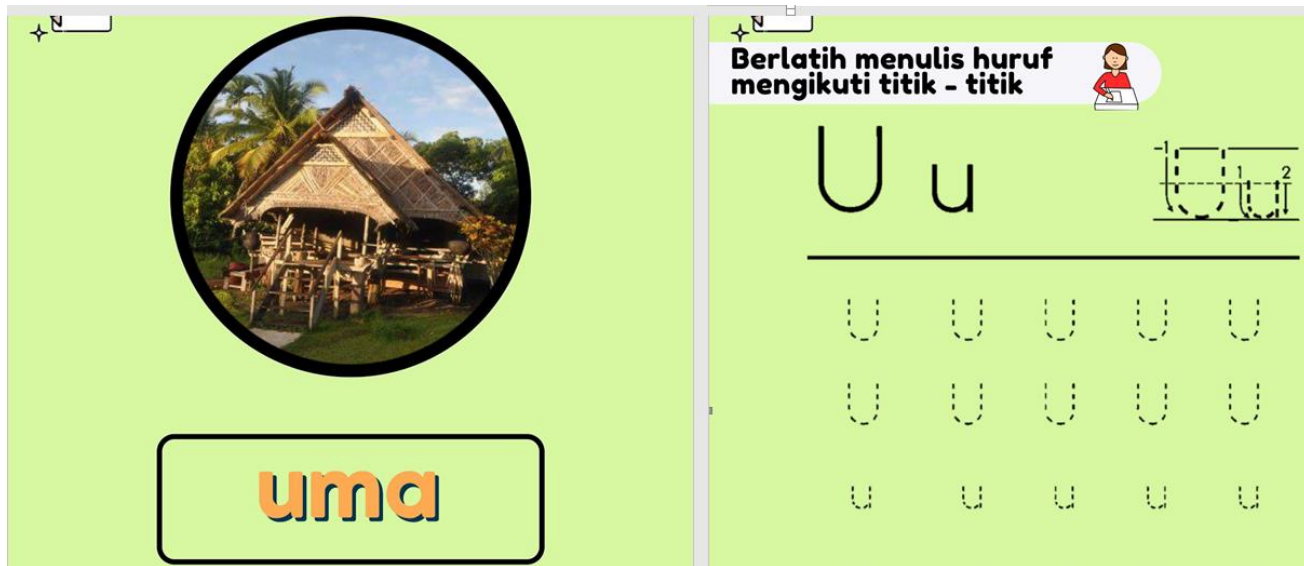

Gambar 2. Mengenalkan huruf U dengan menggunakan kata Uma rumah adat Mentawai

Pada tahap ketiga dalam penelitian ini dilakukan validasi isi.materi buku siswa dan validasi desain buku. Buku siswa dinyatakan layak atau baik dengan kriteria 61 $100 \%$ dari seluruh angket yang dinayatakan dalam memvalidasi. Berikut hasil validasi dari masing-masing validator.

\section{Validasi Ahli Materi}

Validasi isi buku siswa dilakukan oleh dua orang ahli materi yang merupakan guru SD di Siberut Mentawai. Berikut hasil validasi dari ahli materi untuk isi buku siswa. 
Tabel 3. Hasil Validasi Ahli Materi

\begin{tabular}{|c|c|c|c|}
\hline \multirow[t]{2}{*}{ Aspek } & \multirow[t]{2}{*}{ Indikator } & \multicolumn{2}{|c|}{ Hasil } \\
\hline & & Ahli 1 & Ahli 2 \\
\hline \multirow[t]{7}{*}{ Isi Materi } & Kesesuaian materi dengan Kompetensi dasar. & 4 & 5 \\
\hline & Kesesuaian materi dengan indikator. & 4 & 5 \\
\hline & 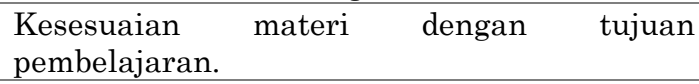 & 4 & 5 \\
\hline & $\begin{array}{l}\text { Kesesuaian materi dengan tingkat kesulitan } \\
\text { dan perkembangan kognitif siswa }\end{array}$ & 5 & 4 \\
\hline & $\begin{array}{l}\text { Materi yang disajikan runtut dan mudah } \\
\text { dipahami. }\end{array}$ & 4 & 4 \\
\hline & Kebermanfaatan materi. & 5 & 4 \\
\hline & $\begin{array}{l}\text { Keterkaitan materi dengan kehidupan sehari- } \\
\text { hari. }\end{array}$ & 5 & 4 \\
\hline \multirow[t]{4}{*}{ Keakuratan Materi } & Keakuran konsep dan definisi. & 5 & 4 \\
\hline & Keakuratan data dan fakta. & 5 & 5 \\
\hline & Keakuratan contoh. & 5 & 5 \\
\hline & Kekuatan gambar dan ilustrasi. & 5 & 5 \\
\hline \multirow[t]{4}{*}{ Kebahasaan } & Kesesuaian bahasa dengan PUEBI. & 4 & 4 \\
\hline & Kejelasan petunjuk penggunaan buku. & 5 & 5 \\
\hline & $\begin{array}{l}\text { Keterangan gambar memberikan informasi } \\
\text { yang jelas. }\end{array}$ & 5 & 5 \\
\hline & $\begin{array}{l}\text { Bahasa yang digunakan sesuai dengan tingkat } \\
\text { perkembangan siswa }\end{array}$ & 5 & 4 \\
\hline \multicolumn{2}{|l|}{ Jumlah } & 70 & 68 \\
\hline \multicolumn{2}{|l|}{ Persentase } & 93 & 91 \\
\hline \multicolumn{2}{|c|}{ Kualifikasi/Predikat } & $\begin{array}{c}\text { Sangat } \\
\text { Baik }\end{array}$ & $\begin{array}{c}\text { Sangat } \\
\text { Baik }\end{array}$ \\
\hline
\end{tabular}

Berdasarkan hasil penilaian pada tabel 1 menunjukkan jumlah skor yang diperoleh dari ahli materi 1 sebesar 70 dan dari ahli materi 2 sebesar 68 dari skor total 75 maka rata-rata persentase hasil validasi ahli materi diperoleh rata-rata persentase $92 \%$ yang artinya buku siswa memiliki kualifikasi/predikat sangat baik.

\section{Validasi Ahli Media}

Validasi desain buku dilakukan oleh 3 dosen ahli media. Berikut hasil validasi desain buku siswa oleh ahli media

Tabel 4. Hasil Validasi Ahli Media

\begin{tabular}{|c|c|c|c|c|}
\hline \multirow{2}{*}{\multicolumn{2}{|c|}{ Aspek dan Indikator }} & \multicolumn{3}{|c|}{ Hasil } \\
\hline & & Ahli 1 & Ahli 2 & Ahli 3 \\
\hline \multirow[t]{2}{*}{ Ukuran } & $\begin{array}{l}\text { 1. Kesesuaian buku dengan standar } \\
\text { ukuran ISO }\end{array}$ & 5 & 5 & 5 \\
\hline & $\begin{array}{l}\text { 2. Kesesuaian ukuran dengan materi isi } \\
\text { buku }\end{array}$ & 5 & 5 & 5 \\
\hline \multicolumn{5}{|l|}{ Cover Buku } \\
\hline \multirow[t]{5}{*}{$\begin{array}{l}\text { Tata Letak Kover } \\
\text { Buku }\end{array}$} & $\begin{array}{l}\text { 1. Penataan unsur tata letak pada cover } \\
\text { muka, belakang, dan punggung } \\
\text { memiliki satuan. }\end{array}$ & 5 & 5 & 5 \\
\hline & $\begin{array}{l}\text { 2. Penataan tata letak unsur pada } \\
\text { muka, punggung, dan belakang } \\
\text { sesuai/harmonis memberikan kesan } \\
\text { irama yang baik. }\end{array}$ & 5 & 5 & 5 \\
\hline & $\begin{array}{l}\text { 3. Menampilkan pusat padang (point } \\
\text { center) yang baik dan jelas }\end{array}$ & 4 & 5 & 4 \\
\hline & $\begin{array}{l}\text { 4. Komposisi unsur tata letak (judul, } \\
\text { pengarang, islustrasi, logo, dll) } \\
\text { seimbang dan seirama dengan tata } \\
\text { letak isi. }\end{array}$ & 3 & 5 & 4 \\
\hline & 5. Ukuran unsur tata letak proporsional & 5 & 5 & 4 \\
\hline
\end{tabular}




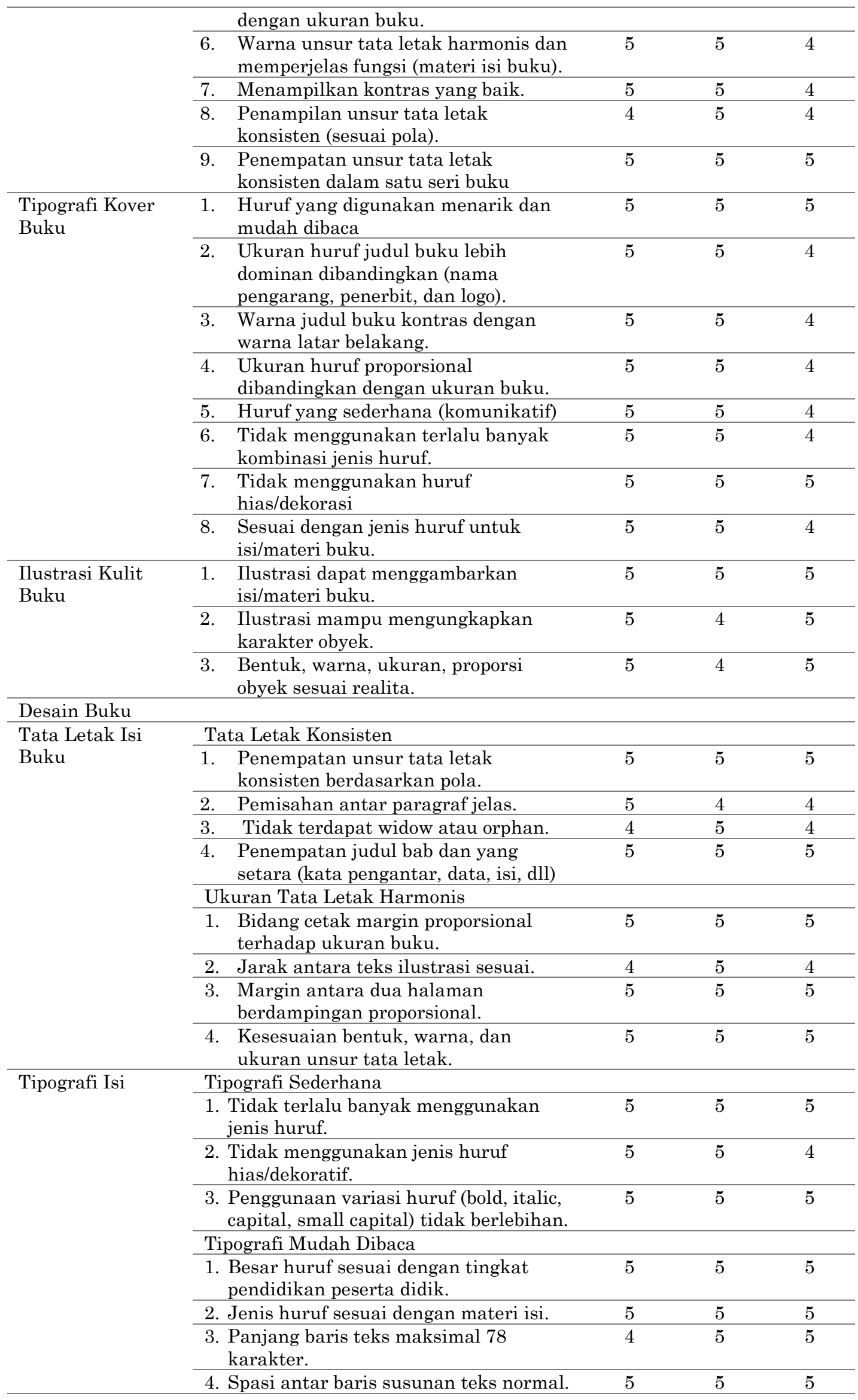




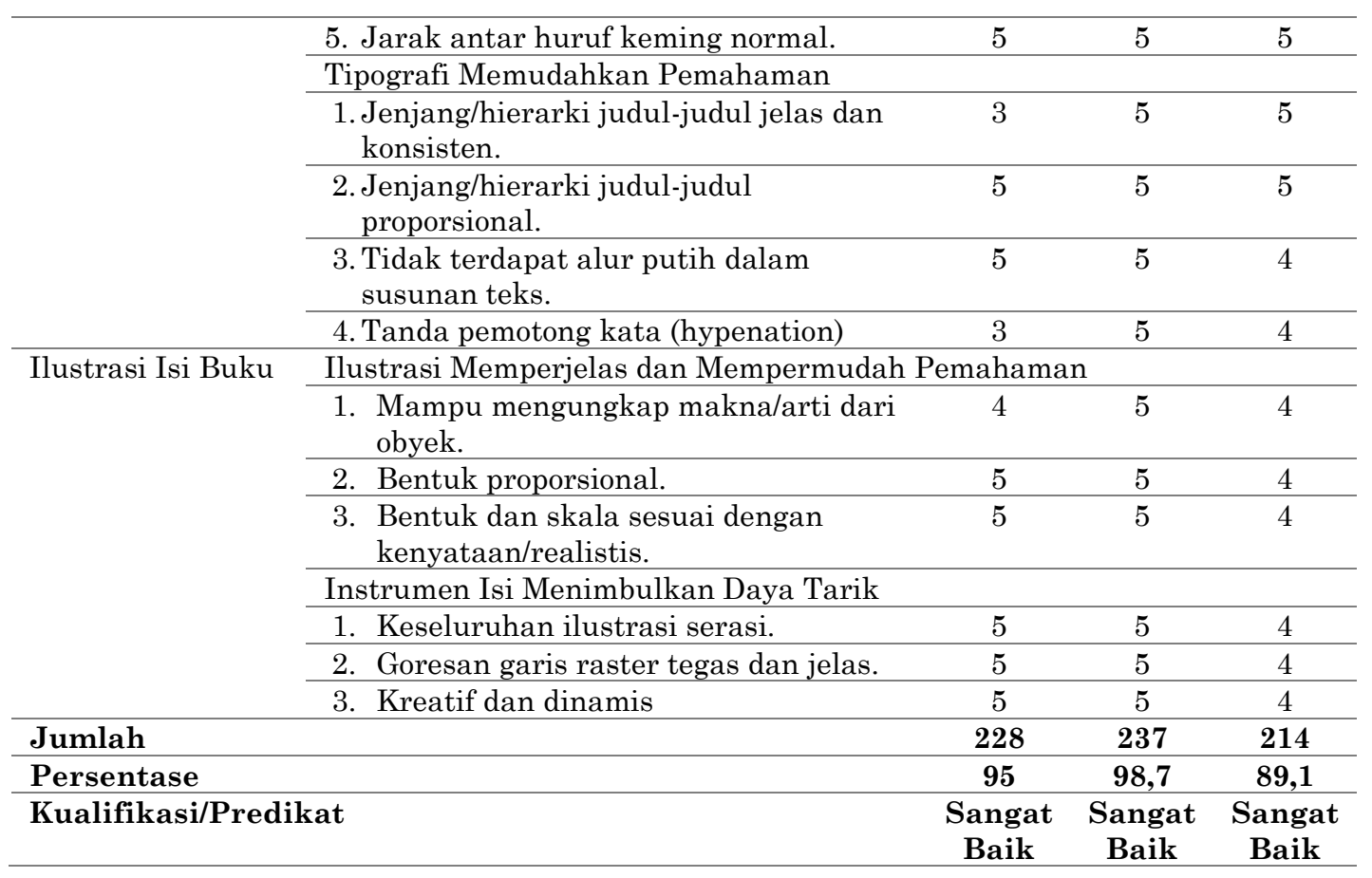

Berdasarkan hasil penilaian pada tabel 2 menunjukkan jumlah skor yang diperoleh dari ahli media 1 sebesar 228, ahli media 2 sebesar 237, dan ahli media 3 sebesar 214 dari skor total 240, maka rata-rata persentase hasil validasi ahli media diperoleh $94,26 \%$ yang artinya buku siswa memiliki kualifikasi/predikat sangat baik.

Tahap keempat: implementasi. Produk buku siswa yang sudah divalidasi oleh ahli materi dan ahli media selanjutnya dicetak dan diujicobakan ke guru dan siswa. Uji coba ke siswa dilakukan dua kali yaitu uji coba satu satu dan uji coba kelompok kecil. Uji coba satu satu dilakukan terhadap 4 siswa dan uji coba kelompok kecil dilakukan terhadap 26 siswa. Dalam kegiatan uji coba baik guru maupun siswa menggunakannya dalam pembelajaran, Setelah selesai menggunakan buku siswa dalam pembelajaran selanjutnya peneliti melakukan wawancara untuk mendapat informasi terkait kelayakan buku. Berikut hasil uji coba yang peneliti lakukan.

Uji coba buku ke guru dilakukan untuk menilai kelayakan buku siswa. Aspek-aspek yang dinilai mencakup isi buku, pengaplikasian dalam pembelajaran, dan manfaat yang dirasakan. Dari Hasil l uji coba terhadap guru diperoleh informasi bahwa buku siswa membangkitkan semangat siswa untuk belajar karena berwarna dan ukuran huruf tepat. Buku mengarahkan siswa secara bertahap untuk belajar membaca dan menulis. Siswa dapat terfasilitasi rasa ingin tahunya dan terlihat gembira dalam belajar membaca menulis.

Uji coba satu satu kepada 4 siswa dilakukan dengan cara peneliti berinteraksi secara individual melalui observasi dan wawancara mendalam. Hasil uji coba satu-satu diperoleh informasi bahwa petunjuk penggunaan buku jelas, gambar dan warna buku menarik sehingga siswa merasa semangat dalam belajar.

Uji coba kelompok kecil kepada 24 siswa dilakukan dengan cara meminta siswa mengerjakan latihan yang ada di buku dan diberi pertanyaan untuk mengetahui pemahaman siswa setelah bekajar dengan menggunakan buku siswa membaca menulis permulaan. Hasil uji coba kelompok kecil menunjukkan siswa dapat menggunakan buku dengan baik karena petunjuk penggunaan buku jelas, gambar dan warna menarik sehingga siswa bersemangat dalam belajar. Selain itu buku mudah digunakan sehingga siswa tidak merasa kesulitan dalam mengerjakan latihan yang ada di buku. 


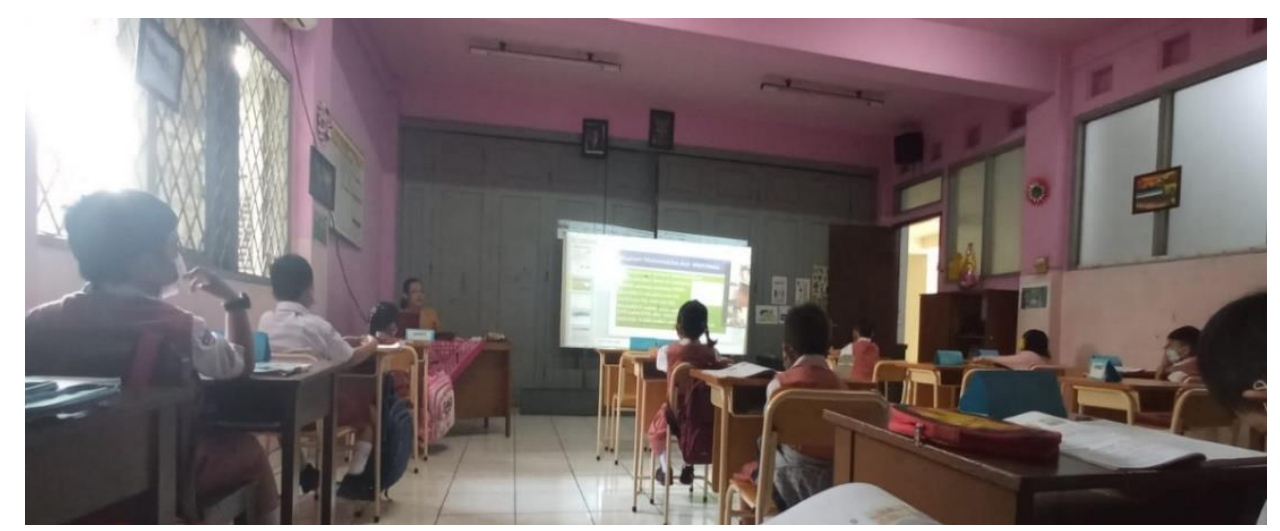

\section{Pembahasan}

Gambar 3. Uji Coba Kelompok Kecil

Penelitian pengembangan buku siswa dilakukan melalui 4 tahapan dengan menggunakan model ADDIE. Berdasarkan hasil pada tahap pengembangan pertama yaitu tahap anilis, peneliti mengembangkan buku siswa membaca menulis permulaan dengan melihat kebutuhan, keterbatasan, serta permasalahan yang dialami guru dan siswa. Buku siswa yang akan dikembangkan didesain semenarik mungkin dan dikembangkan berbasis budaya setempat supaya memudahkan siswa dalam belajar. Hal tersebut sejalan dengan yang disampaikan Piage (dalam Marhaeni, 2013) bahwa anak usia SD berada pada tahap operasional konkrit maka diperlukan pengembangan buku siswa yang bisa melatih, memperkuat, dan mempertajam keterampilan siswa dalam memecahkan masalah logis sesuai dengan kondisi lingkungan budaya siswa.

Desain buku menggambarkan keseluruhan hubungan antar bagian dalam buku siswa. Desain buku dibuat untuk memudahkan proses pembuatan buku selanjutnya dan berfungsi sebagai panduan dalam pembuatan busu siswa. Sampul dan judul buku dibuat dengan ukuran yang besar dengan aneka ukuran dan warna agar menarik siswa untuk belajar membaca menulis permulaan. Struktur penulisan buku dikembangkan untuk memfasilitasi pengalaman belajar yang bermakna berdasarkan peta kompetensi: mengenal huruf abjad, mewarnai dan menemukan huruf, serta mengenal suku kata. Materi pengenalan huruf dimulai dengan pengenalan huruf vokal terlebih dahulu, setelah itu dilanjutkan dengan pengenalan huruf konsonan. Hal tersebut sejalan dengan yang disampaikan Usawatun (dalam Nahel, 2012: 1) bahwa buku harus disusun secara sistematis dan bertahap.

Selanjutnya untuk mendapatkan buku siswa berbasis budaya lokal yang valid, dilakukan validasi terhadap buku siswa berbasis budaya lokal. Menurut Vieven dalam Fatmawati (2016: 99) "penilaian validitas perangkat pembelajaran diukur berdasarkan hasil validasi", hasil validasi ahli materi diperoleh rata-rata presentase $92 \%$ dari dua ahli materi. Hasil validasi ahli media diperoleh rata-rata presentase 94,26\% dari tiga ahli media. Dengan demikian sesuai dengan kriteria kelayakan menurut Arikunto (2008:35) buku siswa yang dikembangkan secara keseluruhan memiliki kualifikasi sangat baik dan tidak perlu direvisi. Akker (dalam Sofnidar \& Sabil, 2012) mengatakan bahwa kualitas buku sebagai perangkat pembelajaran setidaknya dilihat dari kriteria kevalidan, keefektifan, dan kepraktisan.

Hasil uji coba pengunaan buku yang dilakukan kepada guru dan siswa diperoleh data bahwa buku siswa membangkitkan semangat dan minat siswa untuk belajar karena berwarna dan tulisannya tidak terlalu besar dan tidak terlalu kecil. Minat siswa memiliki pengaruh yang besar dalam membaca. Hasanah (dalam Widiyati, 2013) mengatakan bahwa minat baca menentukan tujuan membaca. Selanjutnya 
buku mengarahkan siswa secara bertahap untuk belajar membaca menulis permulaan. Siswa dapat terfasilitasi rasa ingin tahunya dan terlihat bersemangat dalam belajar membaca menulis. Hal tersebut sejalan dengan pendapat Prastowo (2011:79) buku siswa disusun menggunakan bahasa sederhana, menarik, dan dilengkapi gambar sehingga akan sangat membantu guru dan siswa dalam mendalami ilmu pengetahuan sesuai dengan mata pelajaran masing-masing. Berdasarkan penelitian yang dilakukan Haryanto (2009: 157), hasil pengembangan yang dikembangkan berdasarkan kebutuhan memiliki kegunaan yang tinggi.

\section{Simpulan}

Berdasarkan hasil penelitian dan pembahasan dapat disimpulkan bahwa buku siswa yang dikembangkan untuk siswa belajar membaca dan menulis permulaan pada isi buku siswa berkategori sangat baik dari aspek isi materi, keakuratan materi, kebahasaan dengan akumulasi dari rentang skor validitas yakni $92 \%$, sedangkan desain buku siswa berkategori sangat baik dari aspek ukuran buku, desain cover buku, desain isi buku, ilustrasi isi buku dengan akumulasi dari rentang skor validitas yakni $94,26 \%$. Hal ini menunjukkan bahwa buku siswa dapat digunakan dalam kegiatan pembelajaran. Hasil analisis memperoleh kriteria A (81\%-100\%), maka buku siswa kualifikasinya sangat baik untuk digunakan dalam pembelajaran. Berdasarkan hasil uji coba yang dilakukan diperoleh data bahwa materi yang ada dalam buku jelas bagi siswa, memberi dampak positif, dan buku layak untuk digunakan. Jadi, buku siswa membaca menulis permulaan berbasis budaya yang dikembangkan dikatakan layak untuk digunakan dalam kegiatan pembelajaran.

\section{Saran}

Saran yang dapat diberikan dari penelitian ini adalah;

1. Peneliti berikutnya dapat mengembangkan buku siswa berbasis budaya Mentawai lanjutan dari buku yang sudah dikembangkan sesuai dengan kompetensi dasar lanjutan yang terdapat dalam kurikulum.

2. Peneliti berikutnya dapat mengembangkan buku siswa membaca menulis permulaan berbasis budaya untuk daerah lain yang ada di Indonesia agar pembelajaran menjadi lebih bermakna dan kontekstual.

\section{Referensi}

Prastowo, P. (2011). Panduan Kreatif Membuat Bahan Ajar Inovatif. Yogyakarta: Diva Press.

Arikunto, S. (2008). Prosedur Penelitian Suatu Pendekatan Praktik. Jakarta: Rineka Karya.

Artapati, L., W., \& Budiningsi, A. (2017). Pelaksanaan Kurikulum 2013 di SD Negeri Serayu Yogyakarta. Jurnal Inovasi Teknologi Pendidikan, 4(2).

Biro Komunikasi dan Layanan Masyarakat Kementerian Pendidikan dan Kebudayaan. (3 Desember 2019). Hasil PISA Indonesia 2018: Akses Makin Meluas, Saatnya Tingkatkan Kualitas. Diakses 28 Februari 2020, dari https://www.kemdikbud.go.id/main/blog/2019/12/hasil-pisa-indonesia-2018akses-makin-meluas-saatnya-tingkatkan-kualitas.

Branch, R. M. (2009). Instrictional Design-The ADDIE Approach. New York: Springer.

Fatmawati, A. (2016). Pengembangan Perangkat Pembelajaran Konsep Pencemaran Lingkungan Menggunakan Model Pembelajaran Berdasarkan Masalah Untuk SMA Kelas X. Jurnal Edusains, 4(2), 2338-4387. 
Gumono. (2020). Analisis Bahan Ajar Membaca yang Tersedia Untuk Siswa Sekolah Dasar di Provinsi Bengkulu. Jurnal Ilmiah Pendidikan Guru Sekolah Dasar, 13(1), 47-57.

Haryanto. (2009). Upaya Meningkatkan Kemampuan Membaca dan Menulis Permulaan dengan Media Gambar. https://digilib.uns.ac.id/upaya meningkatkan, 1-164. Diakses 22 Februari 2020.

Nahdi, K. \& Dukha, Y, (2020). Literasi Berbahasa Indonesia Usia Pra Sekolah: Ancangan metode Dia Tampan Dalam Membaca Permulaan. Jurnal Obsesi: Jurnal Pendidikan Anak Usia Dini, 4(1), 446-453.

Marhaeni. (2013). Landasan dan Inovasi Pembelajaran. Undiksha: Singaraja.

Mutiah, D. (2010). Psikologi Bermain Anak Usia Dini. Jakarta: Kencana Prenada Media Group.

Nahel, B. (2012). Pengertian Buku Siswa. (online) tersedia di http://id.shvoong.com/social-sciences/education/2251813-pengertian-bukusiswa/ diunduh pada tanggal 28 Februari 2020.

Sofnidar \& Sabil. (2012). Pengembangan Bahan Ajar Matematika I dengan Pendekatan Kontekstual. Jurnal Pendidikan Matematika, 2(2).

Sugiyono. (2014). Metode Penelitian Pendidikan Pendekatan Kuantitatif, Kualitatif, dan $R \& D$. Bandung: Alfabeta.

Sukartiningsih, W. (2005). Peningkatan Kemampuan Membaca dan Menulis Permulaan Melalui Pembelajaran Konstruktivisme. Jurnal Pendidikan Dasar, (6) 2.

Widiyati, E. (2013). Peningkatan Minat Dan Kemampuan Membaca Permulaan Melalui Media Buku Cerita Binatang Dan Permainan Bahasa Siswa Kelas II SD Plus Al-Anwar Pacul Gowang Jombang. Jurnal Pendidikan Humaniora, 1(4), 405-413. 